\title{
Extract from "The effects of strenuous exertion on women"-Practitioner, 1956
}

Because of their structure and function, women were for long regarded as ineligible to compete in games to any extent. Many of these restrictions to activity are still commonly accepted, often without foundation, and the medical profession must accept its share of responsibility for this perpetuation of unnecessary restrictions. Modern woman is a far cry from her Neanderthal counterpart whose life depended upon her ability to run, jump and throw. In spite of her rigorous life, she bore her young and the world continued to grow. Temple-racing of Hebrew mythical-ritual significance, took place at certain seasons of the year when the young men and women of Jerusalem raced two miles round the temple Hippodrome (Patai, 1947). It is recorded in Greek mythology that Atlanta, the huntress, challenged all suitors to a foot race, and on beating them stabbed them in the back. Milanion, before racing Atlanta, was given three golden apples by Aphrodite and these he dropped one at a time when he was in danger of being caught up. Thus Milanion was able to win race and wife. Pausanius describes how Greek women had their own Olympic Games, called Heraea, after Hera, wife and sister of Zeus. These consisted of foot races of 150 metres. Spartan women were regarded as the mothers of Spartan supermen, so that girls were trained in wrestling and boxing, and ran races against boys. In the fairs and wakes of the eighteenth century, English women competed in foot races. Louis Bourgeois, a pupil of Ambroise Paré, and who officiated at the birth of the Dauphin (later Louis XIII), disapproved of the then current teaching that "a woman, seven months gone ought to walk very much".

DAVID RYDE

Founder member of BASM

Reproduced, with permission, from The Practitioner 